\section{Political Economy and the Question of Freedom: Notes on Hegel and Marx}

La economía política y la cuestión de la libertad: Notas sobre Hegel y Marx

\author{
Márcio Egídio Schäfer
}

\begin{abstract}
The reception of classical political economy played a prominent role in the development of Hegel's and Marx's political thought. The purpose of this paper is twofold: firstly, to present the general outlines of the reception of classical political economy in Hegel and Marx; secondly, to evaluate the implications of the reception of classical political economy in the concept of freedom in both philosophers. I argue that the reception of classical political economy, due to different philosophical standpoints, leads Hegel and Marx to develop a different conceptualization of freedom. My main concern was to provide not an exhaustive analysis of the topic but a brief sketch of the implications which different interpretations of political economy have on the question of freedom, indicating, if that should be the case, works that may shed more light on some of the issues addressed throughout the contribution.
\end{abstract}

Keywords: Hegel; Marx; political economy; freedom

\section{RESUMEN}

La recepción de la economía política clásica desempeñó un papel destacado en el desarrollo del pensamiento político de Hegel y Marx. El propósito de este trabajo es doble: en primer lugar, presentar las líneas generales de la recepción de la economía política clásica en Hegel y Marx; en segundo lugar, evaluar las implicaciones de la recepción de la economía política clásica en el concepto de libertad en ambos filósofos. Sostengo que la recepción de la economía política clásica, debido a los diferentes puntos de vista filosóficos, lleva a Hegel y a Marx a desarrollar una conceptualización diferente de la libertad. Mi principal preocupación es ofrecer, no un análisis exhaustivo del tema, sino un breve esbozo de las implicaciones que las diferentes interpretaciones de la economía política tienen en la cuestión de la libertad, indicando, si es el caso, trabajos que puedan arrojar más luz sobre algunas de las cuestiones abordadas a lo largo de la contribución.

Palabras clave: Hegel; Marx; economía política; libertad
INFORMATION

https://doi.org/10.46652/resistances.v2i4.70 ISSN 2737-6222 |

Vol. 2 No. 4, 2021, e21056

Quito, Ecuador

Submitted: October 31, 2021

Accepted: December 17, 2021

Published online: December 30, 2021

Continuous publication

Dossier Section | Peer Reviewed

AUTHOR

Márcio Egídio Schäfer Federal University of Maranhão - Brazil schafer.marcio@ufma.br

Conflict of interest No potential conflict of interest is reported by the author. Funding

No financial assistance from parties outside this article. Acknowledgments N/A

PUBLISHER

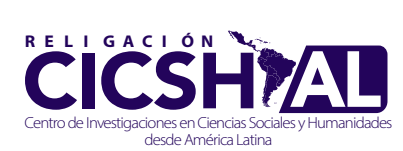




\section{Hegel's Reception of Classical Political Economy}

It can be rightly said that Hegel was the first philosopher to comprehensively engage with modern political economy, submitting its far-reaching implications in the political community (Das sittliche Gemeinwesen) to a profound philosophical inquiry. He reflected in details upon the potentials as well as the limitations of the discipline and its impact on the realization of freedom. Although Hegel's discussion with this science underwent a slight change of emphasis during the different phases of his work, from his Early Writings to his late Philosophy of Right this discussion represents a constituent part of his philosophical analysis of the modern society.

On focusing on the systematic core of Hegel's political philosophy, it becomes clear that the reception of modern political economy is decisive to the clarification of one of Hegel's most important contributions to the history of political philosophy, namely the sharp conceptual distinction between civil society and State (see Riedel, 1975). The increasing centrality of the sphere of civil society in Hegel's theory of subjective freedom can be understood in strict relation to this achievement.

If, on the one hand it is true that in his early work Hegel still showed some sympathy for the thesis of a restoration of the idealized beautiful unity of the ancient Greek polis (Plant, 1973); in On the Scientific Ways of Treating Natural Law, on the other hand, the philosopher starts to doubt the plausibility of this thesis. It is reasonable to guess that Hegel's more favorable evaluation of civil society (and its milestone position in the history of the progress of the idea of freedom) were impacted on precisely by the results of the modern science of political economy -with which Hegel became acquainted early on (Lukács, 1973)- with regard to the dynamic of capitalist production and the freedom potentials created by it, especially through the new way of organizing labor.

However, in the Philosophy of Right ( $\$ 243$ ), Hegel indicates that civil society yields at once positive as well as negative results. "The amassing of wealth is intensified by generalizing (a) the linkage of men by their needs, and (b) the methods of preparing and distributing the means to satisfy these needs, because it is from this double process of generalization that the largest profits are derived". So far, we have the positive aspect of civil society. But Hegel (§ 243 ) also remarks that:

\footnotetext{
The other side is the subdivision and restriction of particular jobs. This results in the dependence and distress of the class tied to work of that sort, and these again entail inability to feel and enjoy the broader freedoms and especially the intellectual benefits of civil society.
}

These negative consequences jeopardize the possibility to establish a harmonious social order in modern society.

In $\S 245$, Hegel concludes that: "It hence becomes apparent that despite the excess of wealth civil society is not rich enough, that is, its own resources are insufficient to check excessive poverty and the creation of a penurious rabble". As is well known, the rabble, be it the poor or rich rabble, is the main destabilizing factor of ethical life. The phenomenon of the rabble can, therefore, be characterized as the direct outcome of a society in which reason has been 
overruled by understanding. Only through the subordination of understanding to reason, that is, of civil society to the State, it is possible to establish an equilibrium between these disruptive forces of modern society.

The question that arises is how not to throw out the baby with the bathwater. The task consists in finding an effective counterbalance to the contradictions of civil society in order to prevent a dire collision of interests that could eventually ruin it. In a certain sense Hegel's both early and late reflections are aimed at finding solutions for this tension that pervades modern society. Concerning this topic, the philosopher offers a first statement in his already mentioned On the Scientific Ways of Treating Natural Law.

\begin{abstract}
Da dieses System der Realität ganz in der Negativität und in der Unendlichkeit ist, so folgt für sein Verhältniß zu der positiven Totalität, daß es von derselben ganz negativ behandelt werden, und seiner Herrschaft unterworfen bleiben muß; was seiner Natur nach negativ ist, muß negativ bleiben, und darf nicht etwas festes werden (GW 4, p. 450).
\end{abstract}

This passage from On the Scientific Ways of Treating Natural Law underpins the thesis that the sphere of civil society, the sphere of economic life must be subordinated to a higher sphere, the sphere of the State (of reason). Only by being contained within the limits of the State can modern economy do justice to the progressive elements for the development of the idea of freedom it brought to light. "Dagegen ist Krankheit und der Anfang des Todes vorhanden", as pointed out in On the Scientific Ways of Treating Natural Law, "wenn ein Theil sich selbst organisirt, und sich der Herrschaft des Ganzen entzieht" (GW 4, p. 476). Hegel never abandoned this thesis, so it can be legitimately said that the Philosophy of Right offers a more elaborated philosophical foundation for this crucial idea expressed in Hegel's Early Writings (Rosenfield, 1989; Vieweg, 2012).

Hegel's main conclusion is that the deep rift in modern society cannot be remedied trough the restoration of the beautiful unity of the Greek polis. With this knowledge, he paved the way for his late reflection, according to which civil society is an essential sphere of every free society (Vieweg, 2012, p. 275). This change is associated with the fact that modern juridical and economic relations are no longer conceived as the dissolving power of political community. Rather, they are the cornerstone of subjective freedom. However, this knowledge is insufficient to alleviate the unintended and unwanted self-destructive tendencies related with the emergence of modern society. Therefore, in Hegel's view, only through the integration of civil society in a higher sphere-the sphere of reason, of State-can modern juridical and economic relations genuinely contribute to the realization of subjective freedom. For, as Hegel asserts in $\S 124$ of the Philosophy of Right, subjective freedom "is the pivot and center of the difference between antiquity and modern times".

Beyond this very general consideration of the constitution of political economy as science of civil society and the ensuing freedom potentials, there are two other aspects which are noteworthy in Hegel's evaluation of this science and which highlight his interest in it, one economic and the 
other scientific. Hegel especially praises the scientific achievements of political economy, which he recognizes first of all in its methodological procedures. In the Philosophy of Right as well as in his Encyclopedia of the Philosophical Sciences Hegel himself expresses this point.

With regard to the science of political economy, Hegel concisely affirms in the Philosophy of Right that:

\begin{abstract}
This is one of the sciences which have arisen out of the conditions of the modern world. Its development affords the interesting spectacle (as in Smith, Say, and Ricardo) of thought working upon the endless mass of details which confront it at the outset and extracting therefrom the simple principles of the thing, the Understanding effective in the thing and directing it (\$189).
\end{abstract}

In his Encyclopedia of the Philosophical Sciences, Hegel expresses himself as follows: "Wir heißen jene Wissenschaften, welche Philosophie genannt worden sind, empirische Wissenschaften von dem Ausgangspunkte, den sie nehmen. Aber das Wesentliche, das sie bezwecken und hervorschaffen, sind Gesetze, allgemeine Sätze, eine Theorie; die Gedanken des Vorhandenen" (GW 20, p. 47). And some lines after he re-affirms that: "So heißt insbesondere die den neuesten Zeiten zu verdankende Wissenschaft der politischen Oekonomie, auch Philosophie, was wir rationelle Staatswirthschaft, oder etwa Staatswirthschaft der Intelligenz, zu nennen pflegen" (GW 20, p. 47).

Concerning the scientific achievements of political economy, Hegel posits that, despite its empirical foundation, it succeeded in bringing the chaotic reality of modern economy under universal laws, precisely insofar as it organized this disordered reality by means of understanding. Nonetheless it is impossible to ignore the fact that, in Hegel's view, very different authors and theoretical positions fall under the rubric of "political economists", so that he does not offer any differentiated analysis of these varying theoretical positions.

With reference to the economic aspect of Hegel's reading of political economy proper, the Jena Writings as well the Philosophy of Right reveal unmistakable references to the Scottish origins of Hegel's economic thought (Waszek, 1988). A crystal-clear example to illuminate this thesis is the item A. The System of Needs of the sub-section II Civil Society of the Philosophy of Right. In § 199 a core thesis of the Scottish Enlightenment is unmistakable: "When men are thus dependent on one another and reciprocally related to one another in their work and the satisfaction of their needs, subjective self-seeking turns into a contribution to the satisfaction of the needs of everyone else". And Hegel adds: "That is to say, by a dialectical advance, subjective self-seeking turns into the mediation of the particular through the universal, with the result that each man in earning, producing, and enjoying on his own account is eo ipso producing and earning for the enjoyment of everyone else".

If, on the one hand, it is true that Hegel assumed some core theses of classical political economy like the thesis of the labor of each man for everyone else ( $\S 198$ ), traceable back to Hume and Smith; on the other hand, it would be false to ascribe to Hegel an uncritical reception of classical political economy. Notwithstanding a very positive evaluation of political economy regarding its economical and methodological achievements, Hegel never neglected the problematic points of 
this science and of the society conceptualized by it. Hegel never adopted Smith's thesis of the invisible hand as a means of harmonizing the contradictions of civil society. Likewise, he was well aware of the negative consequences of the modern division of labor upon the workers. With regard to the latest point, Hegel notes that: "Further, the abstraction of one's man production from another's makes work more and more mechanical, until finally man is able to step aside and install machines in his place" (§ 198).

\section{Marx's Reading of Political Economy}

Marx's relationship to political economy is much more complex than Hegel's, especially because of his multifaceted reception of classical political economy, undergoing various stages of development during his career. For instance, in his Economic and Philosophical Manuscripts of 1844 and The Poverty of Philosophy, Marx's criticism of the discipline has a very different conceptual formulation from his late Critique of Political Economy. As Heinrich (2014) asserts, in his earlier writings Marx was still arguing within the theoretical framework of classical political economy, which he was only able to overcome in his late work.

An important impulse toward this progress was certainly Marx's move to London, then: "Das ungeheure Material für Geschichte der politischen Ökonomie, das im Britisch Museum angehäuft ist, der günstige Standpunkt, den London für die Beobachtung der bürgerlichen Gesellschaft gewährt, [...]", so Marx, "bestimmten mich, ganz von vorne wiederanzufangen und mich das neue Material kritisch durchzuarbeiten" (MEW 13, p. 10-11).

To start with the reconstruction of Marx's relationship to classical political economy it seems meaningful to reaffirm the main question addressed by himself to this discipline in the Capital: "Die politische Oekonomie hat nun zwar, wenn auch unvollkommen. Werth und Werthgröße analysirt und den in diesen Formen versteckten Inhalt entdeckt" (MEGA2 II/6, 110). And Marx adds: "Sie hat niemals auch nur die Frage gestellt, warum dieser Inhalt jene Form annimmt, warum sich also die Arbeit im Werth und das Maß der Arbeit durch ihre Zeitdauer in der Werthgröße des Arbeitsprodukts darstellt?” (MEGA2 II/6, p. 110 f.). Strictly speaking, in the passages quoted, Marx is discussing the core question of the necessary connection between value and money, because, according to him, the money-form must be deduced from the value-form, which is the quintessential issue missed by political economists. On this account, Marx suggests that political economy could never explain the intrinsically necessary connection between money and value, assuming that money as common measure of exchange was instituted by convention.

Every one knows, if he knows nothing else, that commodities have a value form common to them all, and presenting a market contrast with the varied bodily forms of their use-values. I mean the money form. Here, however, a task is set us, the performance of which have never yet even been attempted by bourgeois economics, the task of tracing the genesis of this money form, of developing the expression of value implied in the value relation of commodities, from its simplest, almost imperceptible outline, to the dazzling money form. By doing this we shall, at the same time, solve the riddle presented by money (Marx, 1952, p. 19). 
What is decisive in Marx's argument, at least since the manuscript of the so-called Urtext, is that the social forms, like value, money, etc., press themselves ahead, or more precisely, the antecedent form, like value, necessarily and objectively leads to the next, namely the moneyform, without presupposing the reflected action of the social individuals even if these actions are required for the historical realization of these forms. This is a particularly instructive feature of Marx's systematic exposition of the Capital.

The level of the dialectical development of categories (Chapter I) of the Capital is systematically severed from the level of exchange (Chapter II), in which the "guardians" of commodities, the private individuals, appear on the scene. The primacy of social forms, like commodity form, value form, money form, capital form, etc., their achieving independence over the reflected actions of the social individuals is, according to Marx, the main feature of the new form of social domination that follows the emergence of modern society. In the manuscript of the Urtext Marx summarizes this topic with great precision.

Es [money - M.S.] ist keine blos vermittelnde Form des Waarenaustauschs. Es ist eine aus dem Circulationsprocess hervorwachsende Form des Tauschwerths, ein gesellschaftliches Product, das sich durch die Beziehungen, worein die Individuen in der Circulation treten, von selbst erzeugt. Sobald Gold und Silber (oder jede andre Waare) als Werthmaaß und Circulationsmittel (sei es als leztres in ihrer leiblichen Form oder durch Symbol ersezt) sich entwickelt haben, werden sie Geld, ohne Zuthun und Wollen der Gesellschaft. Ihre Macht erscheint als ein Fatum, und das Bewußtsein der Menschen, besonders in gesellschaftlichen Zuständen, die an einer tiefern Entwicklung der Tauschwerthverhältnisse Untergehn, sträubt sich gegen die Macht, die ein Stoff, ein Ding ihnen gegenüber erhält, gegen die Herrschaft des verfluchten Metalls, die als reine Verrücktheit erscheint. Es ist im Geld zuerst, und zwar in der abstraktesten, daher sinnlosesten, unbegreiflichsten Form - eine Form, in der alle Vermittlung aufgehoben ist-worin die Verwandlung der wechselseitigen gesellschaftlichen Beziehungen in ein festes, überwältigendes, die Individuen subsumirendes gesellschaftliches Verhältniß erscheint. Und zwar ist die Erscheinung um so härter, als sie hervorwächst aus der Voraussetzung der freien, willkührlichen, nur durch die wechselseitigen Bedürfnisse in der Production sich aufeinander beziehenden, atomistischen Privatpersonen (MEGA2 II.2, p. 73 f.).

Although Marx criticizes the entire theoretical framework of political economy, as mentioned before, it cannot be overlooked that Marx evaluates the theoretical achievements of each representative of classical political economy, like Smith, Say, and Ricardo, in a very different, if not opposite, manner. This becomes evident in Marx's analysis of the scientific contributions of these authors. Thus, in the Theories of Surplus Value, Marx emphasizes the methodological difficulties of classical political economy and the corresponding solutions offered. 
Smith selbst bewegt sich mit grosser Naivität in einem fortwährenden Widerspruch. Auf der einen Seite verfolgt er den innren Zusammenhang der ökonomischen Categorien [...]. Auf der andren stellt er daneben den Zusammenhang, wie er scheinbar in den Erscheinungen der Concurrenz gegeben ist und sich also dem unwissenschaftlichen Beobachter darstellt, ganz ebenso gut wie dem in dem Proceß der bürgerlichen Production praktisch Befangenen und Interessirten (MEGA2 II/3, p. 816).

According to Marx, Smith's interest was twofold: “Einerseits der Versuch in die innre Physiologie der bürgerlichen Gesellschaft einzudringen; anderseits aber zum Theil erst ihre äusserlich erscheinenden Lebensformen zu beschreiben, ihren äusserlich erscheinenden Zusammenhang darzustellen, und zum Theil noch für diese Erscheinungen Nomenclatur zu finden, und entsprechende Verstandesbegriffe" (MEGA2 II/3, p. 817). In this point Marx's and Hegel's evaluations of Smith coincides insofar as both see the considerable achievement of his theory in the effort to bring the disordered reality of civil society under laws, namely the laws/concepts of understanding. Smith's great merit resides precisely in the fact that he founded many of these concepts.

In Marx's view, Ricardo's remarkable scientific achievement was the knowledge that: “Die Grundlage, der Ausgangspunkt der Physiologie des bürgerlichen Systems-des Begreifens seines innren organischen Zusammenhangs und Lebensprocesses-ist die Bestimmung des Werths durch die Arbeitszeit”. (MEGA2 II/3, p. 817) According to Marx, Ricardo's entire theory is exposed in the first two chapters of the Principles of Political Economy and Taxation, for there the "entwickelten bürgerlichen Productionsverhältnisse, also auch die entwickelten Categorien der politischen Oekonomie" (MEGA2 II/3, p. 820) are confronted with his point of departure, namely the determination of value by the labor time.

Marx, due to his unique appreciation of political economists, notwithstanding his critique of Ricardo, concedes that he achieved a very important result, which is closely related to his development and specification of the labor-value theory. Marx summarizes that Ricardo unveiled “den ökonomischen Gengensatz der Klassen" (MEGA2 II/3, p. 817 f.), which he will later sharply elaborate under the rubric of the irreconcilable contradiction between labor and capital, the fundamental contradiction of civil society. The irreconcilability of this contradiction makes Marx increasingly doubtful about the freedom potentials of civil society.

\section{The Critique of Political Economy and the Question of Freedom}

It was Hegel's great achievement to recognize the relevance of political economy for the development of the concept of freedom. After the decay of the ethical life of the polis, after the dismissal of the immediate unity of the individual with the ethical totality, freedom can only be conceived of with the admission of an autonomous sphere separated from the State. This knowledge was crucial for the development of Hegel's political philosophy. 
If, on the one hand, Hegel asserts the constitutive role of civil society - within which the economic sphere is analyzed - for his theory of freedom, on the other hand, he does not conceal the fact that modern freedom, restricted to the sphere of civil society, would erode itself. This is a remarkable topic, especially if one takes into account that Hegel did not read the third edition of Ricardo's Principles, of 1821, in which Ricardo published for the first time the famous chapter On Machinery, in which he accentuates the inner contradictions of modern economy (Rosenfield, 1989, p. 217; 225 ff.). The fact that Hegel excludes the idea of a restoration of the ethical life of the polis does not mean, however, that Hegel does not undertake the attempt to mediate civil society - now recognized in its undeniable existence - with philosophical aspects of the ethical life of the polis, such as the subordination of economics under politics (Horstmann, 1975).

It should be pointed out that, in the history of philosophy, Plato and Aristotle were faced with the problem of the relationship between economics and politics, and ultimately decided themselves for the State as the responsible sphere for the common good. The universal interest can be realized not in the sphere of economics, guided by the private interests, but solely in the sphere of politics. If modern political philosophy clearly turned against its ancient counterpart, taking the private individual, the social atom, as the ground of political institutions, it seems justified that Hegel was inspired by the theories of Plato and Aristotle in order to deal with the limits and self-destructive potentials of modern freedom. To be sure, not to accomplish a restoration of the ethical life of the polis, but to ground modern freedom rationally on an ethical totality (Ilting, 1975, p. 62 f.).

Marx tackled the question of freedom in a fundamentally different fashion. He agrees with Hegel that, after the bourgeois political revolutions, a restoration of the beautiful unity of the Greek polis is out of the question. He also recognized that modern freedom, guaranteed through the system of right, was an important progress of modern society and even indispensable to understand how capitalist economy works. Although Marx is well-aware of this progress and never understated the political emancipation carried out through bourgeois political revolutions, he posits that the abolition of the relations of personal dependence, as usual in pre-modern societal forms, does not mean the abolition of all relations of dependence at all. Marx soon realized that the abolition of the relations of personal dependence is closely linked with the genesis of a new sort of social relations of dependence, that is, the domination of social forms of civil society over the social individuals.

According to Marx, the domination of social forms is inexplicable at the level of juridical relations precisely because it does not have its origin in these relations. Hence, it needs to be investigated from another prism, and no juridical or political measure can prevent this domination, let alone abolish them. Thus, according to Marx, freedom cannot be realized in terms of the containment of civil society by means of the State, the higher ethical sphere, but requires a fundamental transformation of the economic structure of society. Already in 1845, in the manuscripts of The German Ideology, Marx and Engels pointed out that the institution of communism is "wesentlich ökonomisch" (MEGA2 1/5, p. 101). It is a matter of social, not political emancipation, a thesis which Marx had already postulated in his early work On the Jewish Question (see Zur Judenfrage, 
MEGA2 I/2, p. 162 f.) As a matter of fact, for Marx the synthesis advocated by Hegel between ancient and modern political thought is an oxymoron.

In the Grundrisse Marx presents a three-staged concept of history whose criterion is precisely the gradual abolition of domination, in which he explicitly addressed this matter. "Persönliche Abhängigkeitsverhältnisse (zuerst ganz naturwüchsig)", so Marx points out, "sind die ersten Gesellschaftsformen, in denen sich die menschliche Productivität nur im geringen Umfang und auf isolierten Punkten entwickelt" (MEGA2 II/1.1, p. 90 f.). "Persönliche Unabhängigkeit auf sachlicher Abhängigkeit gegründet”, Marx continues, "ist die zweite grosse Form, worin sich erst ein System des allgemeinen Stoffwechsels, der universalen Beziehungen, allseitiger Bedürfnisse, und universeller Vermögen bildet” (MEGA2 II/1.1, p. 91). Now Marx formulates his fundamental thesis: "Freie Individualität, gegründet auf die universelle Entwicklung der Individuen und die Unterordnung ihrer gemeinschaftlichen, gesellschaftlichen Productivität als ihres gesellschaftlichen Vermögens, ist die $3^{\text {te }}$ Stufe" (MEGA2 II/1.1, p. 91).

The last stage corresponds to what Marx called a "community of free individuals" (Marx, 1952, p. 34). In the Capital Marx gives some hints why freedom is feasible only in this community of free individuals:

The life-process of society, which is based on the process of material production, does not strip off its mystical veil until it is treated as production by freely associated men, and is consciously regulated by them in accordance with a settled plan (1952, p. 35).

The realization of freedom can also only take place when the domination of social forms of bourgeois economy have been superseded, that is, when the material (re-)production of society is brought under control of the "freely associated men".

\section{Concluding Remarks}

If one directs his attention to the methodical facet of the reception of classical political economy in Hegel and Marx, it is possible to find a similar appraisal of the results of this science. It is situated at the standpoint of empirical science, whose methodological procedures it applies to economic reality. Its achievements and shortcomings are investigated on the basis of these procedures. Notwithstanding the fact that Hegel and Marx evaluate in a similar way the methodological/ scientific achievements of political economy, that is, that it brings order to the chaotic reality of modern economic life through its subsumption under the concepts/laws of understanding, it is necessary to add that the Critique of Political Economy challenges the paradigm of this science as such. For Hegel, insofar as the science of political economy remains restricted to the state of understanding (Verstandesstaat) its scientific results are acceptable. In a certain sense this is the confirmation of Marx's thesis in the Paris Manuscripts: "Vorläufig nehmen wir nur noch das vorweg: Hegel steht auf dem Standpunkt der modernen Nationalökonomen" (MEGA2 I.2, p. 292 f.) Hegel offers his critique when the understanding, that is, civil society, tries to expand itself over the sphere of reason, the State. 
Marx, on the contrary, attacks the results of this science proper, insofar as he submits its entire theoretical paradigm to a sharp critique. Marx's central question was essentially one which was not and could not have been formulated by classical political economy on the ground of its theoretical assumptions, that is, the demonstration of the necessary connection with respect to the achieving of independence of the constitutive social forms of modern sociability. Marx's answer to this question leads him to decisive insights with regard to the question of freedom, that is "Es kann also nichts falscher und abgeschmackter sein", so Marx, "als auf der Grundlage des Tauschwerths, des Geldes die Controlle der vereinigten Individuen über ihre Gesamtproduction vorauszusetzen" (MEGA2 II/1.1, p. 91). But exactly this must be the central goal of a society that aims to guarantee the conditions of possibility for the realization of free individuality. According to Marx, only under these circumstances is it possible that "Die universal entwickelten Individuen" submit "deren gesellschaftlichen Verhältnisse als ihre eignen, gesellschaftlichen Beziehungen auch ihrer eignen gemeinschaftlichen Controlle” (MEGA2 II/1.1, p. 94) under their own control.

Therefore, it can be said that, with reference to the realization of freedom, Hegel and Marx developed diametrically opposed theories. And this opposition rests fundamentally upon the different theoretical attitude adopted by both philosophers towards classical political economy. While Hegel restricted himself to integrate political economy within his theory of ethical life, Marx challenged the entire theoretical framework of this science. With his analyses Marx demonstrated that (i) the development of modern civil society has as consequence the establishment of a new form of social domination, namely the domination of social forms; and (ii) that especially the reproduction of one of these forms, namely the capital form, results in the irreconcilable contradiction between laborers and capitalists, a contradiction which at the same time is constitutive of civil society and unsolvable. Based on this recognition, Marx argues that freedom is only feasible in the stage when free individuality is at the center of social organization, that is, the association of free producers. As Rosenfield outlines: "Marx pretende con ello la destrucción de la 'sociedad civil burguesa', mientras que para Hegel, ésta constituye, en sus contradicciones mismas, una figura que, a través del Estado, conduce a las determinaciones de la libertad hacia su cumplimiento" (Rosenfield, 1989, p. 227). According to Marx, in order to grasp the question of freedom, is it not sufficient to aim at the political containment of civil society. Civil society must be superseded in order to lay down the foundations of a society in which free individuality can flourish.

\section{References}

Hegel, G.F.W. (GW 4) (1968). Ueber die wissenschaftlichen Behandlungsarten des Naturrechts, seine Stelle in der praktischen Philosophie, und sein Verhältniß zu den positiven Rechtswissenschaften. In H. Buchner \& O. Pöggeler (Eds.). Gesammelte Werke. Vol. 4. Felix Meiner.

Hegel, G.F.W. (1952). The Philosophy of Right. Translated by T.M. Knox. In Great Books of Western World, Encyclopedia Britannica.

Hegel, G.F.W. (GW 20) (1992). Encyclopädie der Philosophischen Wissenschaften im Grundrisse. In W. Bonsiepen \& H.-C. Lucas (Eds.). Gesammelte Werke. Vol. 20. Felix Meiner. 
Heinrich, M. (2014). Die Wissenschaft vom Wert. Westfälisches Dampfboot.

Horstmann, R.-P. (1975). Über die Rolle der bürgerlichen Gesellschaft in Hegels politischer Philosophie. In: M. Riedel (Ed.). Materialien zu Hegels Rechtsphilosophie 2, (pp. 276-311) Suhrkamp.

Hume, D. (1960). A Treatise of Human Nature. Oxford Clarendon Press.

Ilting K.-H. (1972). Hegels Auseinandersetzung mit der Aristotelischen Politik. In G. Göhler (Ed.). Georg Wilhelm Friedrich Hegel Frühe politische Systeme (pp. 759-785). Ullstein.

Ilting K.-H. (1975). Die Struktur der Hegelschen Rechtsphilosophie. In M. Riedel (Ed.). Materialien zu Hegels Rechtsphilosophie 2, (pp. 52-78) Suhrkamp.

Lukács, G. (1973). Der Junge Hegel. Suhrkamp.

Marx, K. (2009) (MEGA2 I.2). Karl Marx: Werke, Artikel, Entwürfe. März 1843 bis August 1844. Berlin. Akademie Verlag.

Marx, K. (1976) (MEGA2 II.1.1). Karl Marx - Ökonomische Manuskripte 1857/1858. In Marx \& Engels Gesamtausgabe (MEGA). DietzVerlag.

Marx, K. (1980) (MEGA2 II.2). Karl Marx - Ökonomische Manuskripte und Schriften 1858 -1861. In Marx \& Engels Gesamtausgabe (MEGA). DietzVerlag.

Marx, K. (2013) (MEGA2 II.3). Karl Marx - Zur Kritik der politischen Ökonomie (Manuskript 18611863). In Marx \& Engels Gesamtausgabe Akademie Verlag.

Marx, K. (1987) (MEGA2 II.6). Karl Marx - Das Kapital. Kritik der politischen Ökonomie Erster Band, Hamburg - 1872. In Marx \& Engels Gesamtausgabe (MEGA). DietzVerlag.

Marx, K. (1952). The Capital. Translated by Samuel Moore and Edward Aveling, by Engels Edition. In Great Books of Western World. Encyclopedia Britannica.

Marx, K. (1959) (MEW 4). Das Elend der Philosophie. In Marx, Engels Werke (MEW). Vol. 4. Dietz Verlag.

Marx. K. (1969) (MEW 13). Zur Kritik der politischen Ökonomie. In Marx, Engels Werke (MEW). Vol. 13. Dietz Verlag.

Plant, R. (1973). Hegel. George Allen \& Unwin.

Riedel, M. (1975). Hegels Begriff der, bürgerlichen Gesellschaft' und das Problem seines geschichtlichen Ursprungs. In M. Riedel (Ed.). Materialien zu Hegels Rechtsphilosophie 2, (pp. 247-275) Suhrkamp.

Rosenfield, D. (1989). Política y Libertad. La estructura lógica de la Filosofía del Derecho de Hegel. Fondo de Cultura Económica.

Vieweg, K. (2012). Das Denken der Freiheit. Wilhelm Fink.

Waszek, N. (1988). The Scottish Enlightenment and Hegel's Account of "Civil Society". Kluwer Academic Publishers.

\section{AUTHOR}

Márcio Egídio Schäfer. PhD in philosophy from the Humboldt-Universität zu Berlin. M.A. in philosophy from Pontifícia Universidade Católica do Rio Grande do Sul. B.A. in philosophy from the Universidade Federal do Rio Grande do Sul. Full-time professor at the Universidade Federal do Maranhão. 